\title{
RESEARCH ARTICLE \\ The effect of stress and depression on quality of life of pharmacy students in Malaysia
}

\author{
Ali Blebil iD, Juman Dujaili ID, Ali Haider Mohammed (D), Cheng Mun Cheong, Yishan Hoo \\ School of Pharmacy, Monash University Malaysia, Bandar Sunway, Malaysia
}

\author{
Keywords \\ Depression \\ Malaysia \\ Pharmacy student \\ Stress \\ Quality of Life \\ Correspondence \\ Ali Blebil \\ School of Pharmacy \\ Monash University Malaysia \\ Jalan Lagoon Selatan \\ Bandar Sunway \\ 47500 Subang Jaya \\ Selangor \\ aliblebil@yahoo.com
}

\begin{abstract}
Objective: This study aims to determine the prevalence of stress and depression among pharmacy students, evaluate their health related quality of life (HRQoL) in Malaysia. Methods: A cross-sectional study design was conducted among pharmacy students at eight universities from March to May 2020 across Malaysia. Instruments adopted in the survey included perceived stress scale 4 (PSS-4) for stress, patient health questionnaire-9 (PHQ-9) for depression and WHOQOL-BREF for healthrelated quality of life. Results: A total of 441 students participated in the study. The overall PSS-4 score mean was 7.30 and the differences in PHQ-9 scores mean between public and private universities were not significant. A positive correlation was observed between total PSS-4 scores and PHQ-9 scores. Only $24.5 \%$ of pharmacy students reported a good quality of life, with a median score of 96.00. A Significant negative correlation was found between stress and depression against the quality of life. Conclusions: Stress and depression play a significant role in deteriorating the quality of life of pharmacy students. This highlighted the importance of future research in developing useful interventions to improve the quality of life of university students, especially students from the medical and health science fields.
\end{abstract}

\section{Introduction}

Health-related quality of life (HRQoL) includes the perceived wellbeing of physical, mental, and social domains of health (Gurková, 2011). Over the years, selfassessed HRQoL has become increasingly recognised and acknowledged as a useful indicator to evaluate a person's health condition and capable of functioning as a surveillance system to monitor the health status of a population (Hennessy et al., 1994). Many factors can affect HRQoL of pharmacy students. Findings from a previous study indicated that senior pharmacy students who received more placement opportunities generally exhibited better quality of life (QoL) than the freshmen (Unni et al., 2015).

Stress is defined as a state of physiological and psychological imbalance resulting from the disparity between situational demand and the individual's ability and motivation to meet those needs (Keerthi \& Madhuri). University students are found to have a higher prevalence of anxiety, depression and stress level as compared to the general population (Bayram \& Bilgel, 2008; Beiter et al., 2015; Bidwal et al., 2015; Shamsuddin et al., 2013). This particularly applies to the students in medical, dental, pharmacy or nursing fields. Henning, Ey and Shaw surveyed 988 health profession students and concluded that pharmacy students have a higher level of psychological distress compared to nursing, dental or medical students (Henning, Ey, \& Shaw, 1998). In general, stress has a negative impact on HRQoL, as it significantly affects the physical and psychological health domains in HRQoL, in which higher stress level are related to a poorer QoL (Alkatheri et al., 2020). 
Depression is characterised by sadness, loss of interest or pleasure, feelings of guilt or low self-worth, disturbed sleep or appetite, tiredness, and low concentration. Studies carried out on students from various health science faculties in different universities across the world have suggested that depression is a fairly common issue existing among health professions students (Basudan, Binanzan, \& Alhassan, 2017; Fawzy \& Hamed, 2017; Hunt \& Gable, 2013; Ibrahim \& Abdelreheem, 2015; Nahar et al., 2019; Xu et al., 2014). Depression is associated with low HRQoL (Brown et al., 2010). A recent longitudinal study among Brazilian medical students linked the high prevalence and incidence of mental health disorders with poorer QoL in the follow up (Moutinho et al., 2019). On top of that, if students happen to experience depressive symptoms, this may further deteriorate their quality of life already affected by stress (Ribeiro et al., 2018; Seo et al., 2018). According to Gorczynski and colleague's study, the significance of paying attention to stress and depression in students who are in university lies in identifying how the environment and variables can be altered to induce an improved quality of life. Pharmacy students are also noted to be among the majority of students who have higher levels of stress due to the rigorous nature of their studies, and the highly demanding hours (Gorczynski et al., 2017; McCormack et al., 2018). These factors were amplified by the backdrop of the COVID-19 pandemic, which drastically impacted the daily life of all students worldwide (AlAteeq, Aljhani, \& AlEesa, 2020; Aslan, Ochnik, \& Çınar, 2020; Yang, Chen, \& Chen, 2021).

Most studies on pharmacy students have been conducted in countries beyond Malaysia, highlighting the need to investigate the prevalence of stress, depression and HRQoL among Malaysia pharmacy undergraduates. This study therefore aims are to identify the prevalence of stress and depression among pharmacy students, evaluate their HRQoL, and evaluate potential determinants for different mental health wellbeing.

\section{Methods}

\section{The Study design, participants and setting}

A cross-sectional design was adopted in this study, whereby the data collection was held from March to May 2020. An online survey questionnaire was created using SurveyMonkey and distributed to the targeted participants from eight universities in Malaysia. It was estimated around 2500 eligible pharmacy students, at both private and public universities, were invited using the snowball sampling method through different social platforms, including WhatsApp, email, Instagram, and Facebook. Targeted participants were aged 18 and above and currently studying a pharmacy degree course. Two reminders were done with three-week intervals after the first distribution to increase the response rate. The anonymity of the respondents was ensured as their names, and current university names were excluded. As this was a voluntary survey, no incentive was given with the completion. Based on the estimated population, a minimum required sample size of 334 was calculated using the Raosoft sample size calculator, with $5.0 \%$ margin of error, $95.0 \%$ confidence level, population size of 20,000 , and $50.0 \%$ response distribution (Raosoft Inc, 2004). To account for $10.0 \%$ of sampling bias, 367 participants were the final required sample size.

\section{Research instruments}

The data collection form was developed using previous studies incorporating different validated scales. The developed items of the questionnaire were based on several previous validated works of literatures (Dyrbye et al., 2006; Hennessy et al., 1994; Hunt \& Gable, 2013; Locke et al., 2007; Marshall et al., 2008; Narakornwit et al., 2019; Opoku-Acheampong et al., 2017; Paro et al., 2010). The questionnaire was divided into four sections, inclusive of personal demographics and three assessment tools. Demographic characteristics included age, gender, race, type of university, mode of learning, and current stay (type of accommodation).

The next section included a Perceived stress scale 4 (PSS-4). It was used in the questionnaire to measure the stress level of participants in the past month. Perceived stress scale measured 'the degree to which situations in one's life are appraised as stressful' (Cohen, Kamarck, \& Mermelstein, 1983). Instead of the original 14 questions, the version used in this study only consisted of four items. Vallejo and colleagues (2018) confirmed PSS-4 is a useful instrument in assessing stress perception levels in the general population (Vallejo et al., 2018). Each item was rated on a point scale range from $0-4,(0$, never; 1 , almost never; 2 , sometimes; 3 , fairly often; 4 , very often). All item scores were combined to produce a total score in the range 0-16 in which a higher score indicated a higher degree of perceived stress. This instrument has been validated among Malaysian population (Sandhu, Ismail, \& Rampal, 2015).

A nine-items validated patient health questionnaire (PHQ-9) was included in the questionnaire to assess 
depression levels of pharmacy students (Sherina, Arroll, \& Goodyear-Smith, 2012). Nine items were used to assess the symptoms and grade the severity of depression in the past two weeks. As to grade the depression severity, students then obtained a score ranging from 0 for 'not at all' to 3 for 'nearly everyday' (Kroenke, Spitzer, \& Williams, 2001). With a score of 27 in total, mild depression was determined by obtaining 5 - 9 points, 10 - 14 points for moderate depression, moderately severe depression was 15 - 19 points whereas 20 - 27 points were classified as severe depression (Hunt \& Gable, 2013). However, the results from the survey was not a clinical diagnosis as it can only be confirmed when a differential diagnosis was ruled out by the clinician during a consultation.

Lastly, the students' HRQoL was measured using the WHOQOL-BREF tool. It was a brief version of WHOQOL 100 developed by WHO in 1998, which consisted of 26 items (WHOQOL Group, 1998). The Malaysian version of this tool was valdidated by Hasanah, Naing, and Rahman (2003). With two items assessing the overall QoL and general health, the remaining items were divided into four domains including physical health (Domain 1), psychological (Domain 2), social relationships (Domain 3) and environment (Domain 4). A 5-point Likert scale was applied in rating each item with values ranging from 1 to 5 ('not at all' to 'extremely/completely' and 'very dissatisfied' to 'very satisfied'). As there were different numbers of items present in each domain, the total obtained scores from each domain vary and were considered as raw scores. The total WHOQOL-BREF scores were calculated by summing up scores from 26 questions. As similar to other positive direction scaling tools, higher scores imply higher QoL (WHOQOL Group, 1998).

\section{Data analysis and statistics}

The responses were first extracted from SurveyMonkey then recorded and analysed using the Statistical Package for the Social Sciences 24 (IBM SPSS Inc., Chicago, IL, USA). Descriptive and inferential statistics were applied; categorical data were presented as percentages and frequencies. Any associations or differences between groups were examined by using Mann-U Whitney and independent t-tests as appropriate. One-way ANOVA and Kruskal-Wallis tests were adopted in finding statistical differences in various outcome variables. Multiple linear regression was used to assess the correlation among stress, depression, and health-related quality of life among pharmacy students. All statistical tests were two-tailed and maintained a significance level $(\alpha)<0.05$ and a confidence interval $(\mathrm{Cl})>95.0 \%$.

\section{Ethical approval}

The ethical approval to conduct the study was given by the Human Ethics Committee of Monash University Malaysia (Project ID: 2020-23468-43377) before the distribution of questionnaires at February 2020. Enrolment in this study was completely voluntary and informed consent was first obtained from the participants by accepting the terms and conditions under the explanatory statement before answering the questionnaire. The confidentiality and privacy of all respondents were assured as only the researchers were able to assess the collected data for academic purposes.

\section{Results}

\section{Sociodemographic characteristics}

A total of 441 (response rate $=17.9 \%$ ) students participated in the study. Out of 441 students, 70 students were excluded because they completed less than $30.0 \%$ of the survey. With an average age of $21.2 \pm 1.50$ years, they were predominantly Chinese $(81.9 \%)$ and female $(77.6 \%)$. Approximately $41.0 \%$ of students reported having other commitments besides study, while $20.8 \%$ reported spending more than six hours doing tasks other than studying or attending online classes (Table I).

Table I: Demographic and background information of the participants $(n=371)$

\begin{tabular}{|c|c|c|}
\hline Item & & No. (\%) \\
\hline Age* (mean & standard deviation) & $21.2(1.5)$ \\
\hline \multicolumn{3}{|l|}{ Gender } \\
\hline & Male & $83(22.4)$ \\
\hline$\bullet$ & Female & $288(77.6)$ \\
\hline \multicolumn{3}{|l|}{ Race } \\
\hline & Malay & $41(11.1)$ \\
\hline & Chinese & 304 (81.9) \\
\hline$\bullet$ & Indian & $12(3.2)$ \\
\hline$\bullet$ & Others & $14(3.8)$ \\
\hline \multicolumn{3}{|c|}{ Type of university** } \\
\hline . & Public & $88(23.7)$ \\
\hline$\bullet$ & Private & $276(74.4)$ \\
\hline \multicolumn{3}{|c|}{ Programme year } \\
\hline & Y1 & $135(36.4)$ \\
\hline & Y2 & $48(12.9)$ \\
\hline & Y3 & $75(20.2)$ \\
\hline$\bullet$ & Y4 & $113(30.5)$ \\
\hline \multicolumn{3}{|c|}{ Learning mode $* * * *$} \\
\hline & Traditional & $59(15.9)$ \\
\hline$\bullet$ & Modern & $311(83.8)$ \\
\hline \multicolumn{3}{|c|}{ Accommodation } \\
\hline$\bullet$ & Home & $241(65.0)$ \\
\hline$\bullet$ & Hostel & $117(31.5)$ \\
\hline$\bullet$ & Friends/Relatives house & $3(0.8)$ \\
\hline$\bullet$ & Other & $10(2.7)$ \\
\hline
\end{tabular}


Table I: Demographic and background information of the participants $(n=371)$ (Continued.)

\begin{tabular}{lll}
\hline Item & No. (\%) \\
\hline Commitment other than study & \\
$\bullet \quad$ Yes & $153(41.2)$ \\
- No & $218(58.8)$ \\
Financial issue & \\
- Yes & $6(1.6)$ \\
- No & $243(65.5)$ \\
- Occasionally & $122(32.9)$
\end{tabular}

Time spent in a day on tasks other than studying
- None
44 (11.9)
- 1-3 hours
141 (38.0)
- 3-6 hours
109 (29.4)
- >6 hours
77 (20.8)

Use of any tobacco products, alcohol or drugs as a stress reliever

$$
\begin{aligned}
& \text { - Yes } 10(2.7) \\
& \text { - No } 341 \text { (91.9) } \\
& \text { - Occasionally } 20 \text { (5.4) }
\end{aligned}
$$

Weight change after joining the pharmacy programme

$$
\begin{array}{lll}
\text { - } & \text { Increased } & 50(13.5) \\
\text { - } & \text { Decreased } & 56(15.1) \\
\text { - } & \text { Unchanged } & 265(71.4)
\end{array}
$$

Physical active state +

$$
\begin{aligned}
& \text { - Not active } 11(3.0) \\
& \text { - Somehow active } 61(16.4) \\
& \text { - Active } 188(50.7) \\
& \text { - Very active } 109 \text { (29.4) }
\end{aligned}
$$

Awareness of any counselling services available in the university

$$
\begin{array}{ll}
\text { - Yes } & 320(86.3) \\
\text { - No } & 51(13.7)
\end{array}
$$

Use of counselling service to seek advice

$$
\begin{array}{ll}
\text { - Yes } & 21(5.7) \\
\text { - No } & 350(94.3)
\end{array}
$$

Assignments/homeworks in a week ++

$$
\begin{array}{lll}
\text { - } & \text { None } & 2(0.5) \\
\text { - } & 1-2 & 150(40.4) \\
\text { - } & 2-4 & 166(44.7) \\
\text { - } & \text { r } & 52(14.0)
\end{array}
$$

Frequency of assessment or examinations

- 1-2 in a week

- Once a week

- Once every fortnight

- Less than 1 in a month

16 (4.3)

Difficulty to keep up with the classmates ++

$$
\begin{array}{ll}
- \text { Yes } & 172(46.4) \\
\text { - No } & 198(53.4)
\end{array}
$$

Feelings of stress about the course

$$
\begin{aligned}
& \text { - Yes } 218(58.8) \\
& \text { - No } 13(3.5) \\
& \text { - Neutral } 140 \text { (37.7) }
\end{aligned}
$$

Thoughts of quitting/changing your course along the way

\begin{tabular}{cll}
$\bullet$ & Yes & $89(24.0)$ \\
$\bullet$ & No & $282(76.0)$ \\
\hline${ }^{*} \mathrm{~N}=361,{ }^{* *} \mathrm{~N}=364,+\mathrm{N}=369,+\mathrm{N}=370$ &
\end{tabular}

\begin{tabular}{|c|c|c|c|c|c|}
\hline $\begin{array}{l}\text { Frequencies / } \\
\text { Items }\end{array}$ & $\begin{array}{l}\text { Never } \\
(\%)\end{array}$ & $\begin{array}{l}\text { Almost } \\
\text { n e v e r } \\
\text { (\%) }\end{array}$ & $\begin{array}{l}\text { Sometimes } \\
\text { (\%) }\end{array}$ & $\begin{array}{l}\text { F a i r I y } \\
\text { often (\%) }\end{array}$ & $\begin{array}{l}\text { Very } \\
\text { of ten } \\
(\%)\end{array}$ \\
\hline $\begin{array}{l}\text { How often have } \\
\text { you felt that you } \\
\text { were unable to } \\
\text { control the } \\
\text { important things } \\
\text { in your life? }\end{array}$ & $12(3.2)$ & $62(16.7)$ & $209(56.3)$ & $67(18.1)$ & $21(5.7)$ \\
\hline $\begin{array}{l}\text { How often have } \\
\text { yo u felt } \\
\text { difficulties were } \\
\text { piling up so high } \\
\text { that you could } \\
\text { not overcome } \\
\text { them? }\end{array}$ & $12(3.2)$ & $69(18.6)$ & $206(55.5)$ & $70(18.9)$ & $14(3.8)$ \\
\hline $\begin{array}{l}\text { How often have } \\
\text { you felt confident } \\
\text { about your ability } \\
\text { to handle your } \\
\text { p e r s o a I } \\
\text { problems? }\end{array}$ & $3(0.8)$ & 19(5.1) & $171(46.1)$ & $161(43.4)$ & $17(4.6)$ \\
\hline $\begin{array}{l}\text { How often have } \\
\text { you felt that } \\
\text { things were going } \\
\text { your way? }\end{array}$ & $3(0.8)$ & $23(6.2)$ & $209(56.3)$ & $126(34.0)$ & $10(2.7)$ \\
\hline
\end{tabular}

\section{Prevalence of stress among pharmacy students}

As the surveys were distributed in March 2020, where Malaysia implemented a fully lockdown and switched all the teaching to online platform due to movement restriction order by the Malaysian government, we were evaluating the perceived stress experienced by the Malaysian pharmacy students (Table II). The mean PSS-4 score of all the participants was $7.30(S . D=2.12)$ with male showing higher mean $(n=83$, mean $=7.34, S . D=$ 2.40) than female $(n=288$, mean $=7.29, S . D=2.04)$. Final year students who were expected to experience higher stress levels obtained the lowest PSS-4 scores $($ mean $=$ 6.72 , S.D $=2.08)$, while year one (Y1) students obtained the highest PSS-4 score of $7.64(S . D=2.184)$ followed by year two $(\mathrm{Y} 2)($ mean $=7.50, \mathrm{~S} . \mathrm{D}=2.03)$ and year three $(\mathrm{Y} 3)$ students (mean $=7.45, S . D=1.96$ ). Type of universities, mode of learning and accommodation did not show any statistical differences in PSS-4 scores (Table III). The association between weight change and PSS-4 scores was significantly different as students who gained weight obtained a higher stress score than those who did not.

Table II: Assessment for stress levels using Perceived Stress Scale 4 (PSS-4) $(n=371)$

\section{Prevalence of depression among pharmacy students}

Based on the response, $42.1 \%$ of the students showed mild depression, $17.4 \%$ had moderate depression, while only $1.9 \%$ demonstrated severe depression. During the 
Table III: Relationships between sociodemographic factors with stress, depression and quality of life $(n=371)$

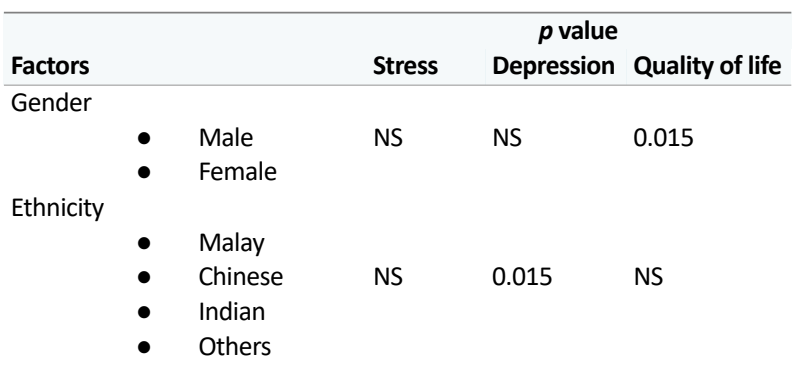

Type of university**

- Public NS NS NS

Programme year

$$
\begin{array}{ll}
- & \mathrm{Y} 1 \\
- & \mathrm{Y} 2 \\
- & \mathrm{Y} 3 \\
\hline & \mathrm{Y} 4
\end{array}
$$

0.003

0.000

0.012

Learning mode $* * * *$

$\begin{array}{llll}\text { - Traditional } & 0.060 & 0.009 & 0.000\end{array}$

Accomodation

- Home

- Hostel

- Friends / Relatives

- Other

Commitment other than study

$$
\begin{array}{llll}
\text { - Yes } & 0.000 & \text { NS }
\end{array}
$$

- No

Commitment other than study

$\begin{array}{cl}\bullet & \text { Yes } \\ \bullet & \text { No } \\ \text { Financial issue } & \\ \bullet & \text { Yes } \\ \bullet & \text { No } \\ \bullet & \text { Occasionally }\end{array}$

other than studying

- None

- 1-3 hours

- 3-6 hours

- $>6$ hours

Use of any tobacco products,

alcohol or drugs as a stress

reliever

$$
\begin{array}{ll}
\text { - } & \text { Yes } \\
\text { - } & \text { No } \\
\text { Occasionally }
\end{array}
$$

Weight change after joining the pharmacy programme

- Increased

Physical active state $* * *$

- Unchanged

- Not active

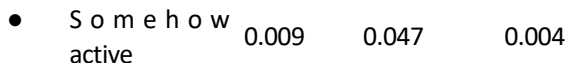

- Active

\begin{tabular}{|c|c|c|c|}
\hline Factors & Stress & $\begin{array}{r}p \text { value } \\
\text { Depression }\end{array}$ & $\begin{array}{l}\text { Quality of } \\
\text { life }\end{array}$ \\
\hline $\begin{array}{l}\text { Use of counselling service to seek } \\
\text { advice } \\
\qquad \begin{array}{ll}\bullet & \text { Yes } \\
& \bullet \quad \text { No }\end{array}\end{array}$ & NS & NS & NS \\
\hline $\begin{array}{l}\text { Assignments/homework in a week } \\
\text { **** } \\
\begin{array}{ll}\bullet & \text { None } \\
\bullet & 1-2 \\
\bullet & 2-4 \\
& -1\end{array}\end{array}$ & NS & NS & NS \\
\hline 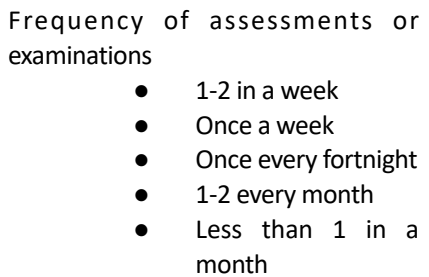 & NS & NS & NS \\
\hline $\begin{array}{l}\text { Difficult to keep up with the } \\
\text { classmates **** } \\
\qquad \text { Yes } \\
\bullet \quad \text { No }\end{array}$ & 0.000 & 0.000 & 0.000 \\
\hline $\begin{array}{cl}\text { Feelings of stress about the course } \\
\bullet \quad \text { Yes } \\
\bullet \quad \text { No } \\
\bullet \quad \text { Neutral }\end{array}$ & 0.000 & 0.000 & 0.000 \\
\hline $\begin{array}{l}\text { Thoughts of quitting/changing your } \\
\text { course along the way } \\
\bullet \quad \text { Yes } \\
\bullet \quad \text { No }\end{array}$ & 0.000 & 0.000 & 0.000 \\
\hline
\end{tabular}

- Very active

Awareness of any counselling services available in the university
Table III: (Continued.)

pandemic, $39.1 \%$ of participants did not feel down, depressed, or hopeless at all, while $51.5 \%$ of the students felt it for several days (Table IV). Significant differences were found between students undergoing traditional and modern mode of learning $(p=0.01)$. Similar to the findings above, Y4 students obtained the lowest depression score across the programme years. Greater levels of depression were observed in students with an increased number of weekly assignments. Those who struggled to keep up with classmates or had the thoughts of quitting the course showed substantially higher depression levels, compared to those who did not suffer from these issues. Gender, accommodation, use of counselling service, frequency of assignments or assessments did not show any significant statistical difference in PHQ-9 scores. A positive moderate correlation was observed between PSS-4 scores and PHQ-9 scores ( $r s=0.49, p=0.01$ ), indicating a proportional relationship between stress and depression. 


\section{Quality of life of pharmacy students}

Only $24.5 \%$ of pharmacy students reported a high quality of life, with a median score of 96.00 (Table V). Similar to the total QoL score, most of the students' scores in each domain fell in the moderate category with 'Physical health' obtaining the highest mean score among the domains.

Table IV: Assessment for depression levels using Patient Health Questionnaire 9 (PHQ-9) (n=371)

\begin{tabular}{|c|c|c|c|c|}
\hline Frequencies / Items & $\begin{array}{l}\text { Not at all } \\
\mathrm{n}(\%)\end{array}$ & $\begin{array}{l}\text { Several } \\
\text { days } \\
\mathrm{n}(\%)\end{array}$ & $\begin{array}{l}\text { M o } r e \\
\text { than half } \\
\text { of } t h e \\
\text { days } \\
\mathrm{n}(\%)\end{array}$ & $\begin{array}{l}\text { Nearly } \\
\text { everyday } \\
\text { n (\%) }\end{array}$ \\
\hline $\begin{array}{l}\text { Little interest or pleasure in } \\
\text { doing things? }\end{array}$ & $67(18.1)$ & $215(58.0)$ & $60(16.2)$ & $29(7.8)$ \\
\hline $\begin{array}{l}\text { Feeling down, depressed, or } \\
\text { hopeless? }\end{array}$ & $145(39.1)$ & $191(51.5)$ & $23(6.2)$ & $12(3.2)$ \\
\hline $\begin{array}{l}\text { Trouble falling or staying } \\
\text { asleep, or sleeping too } \\
\text { much? }\end{array}$ & $99(26.7)$ & $162(43.7)$ & $46(12.4)$ & $64(17.3)$ \\
\hline $\begin{array}{l}\text { Feeling tired or having little } \\
\text { energy? }\end{array}$ & 73(19.7) & 189(50.9) & $58(15.6)$ & $51(13.7)$ \\
\hline Poor appetite or overeating? & $210(56.6)$ & $112(30.2)$ & $31(8.4)$ & $18(4.9)$ \\
\hline $\begin{array}{l}\text { Feeling bad about yourself - } \\
\text { or that you are a failure or } \\
\text { have let yourself or your } \\
\text { family down? }\end{array}$ & $192(51.8)$ & $123(33.2)$ & $38(10.2)$ & $18(4.9)$ \\
\hline $\begin{array}{l}\text { Trouble concentrating on } \\
\text { things, such as reading the } \\
\text { newspaper or watching } \\
\text { television? }\end{array}$ & $161(43.4)$ & $146(39.4)$ & $43(11.6)$ & $21(5.7)$ \\
\hline $\begin{array}{l}\text { Moving or speaking so } \\
\text { slowly that other people } \\
\text { could have noticed? } \\
\text { Or the opposite - being so } \\
\text { fidgety or restless that you } \\
\text { have been moving around a } \\
\text { lot more than usual? }\end{array}$ & $272(73.3)$ & 74(19.9) & $16(4.3)$ & $9(2.4)$ \\
\hline $\begin{array}{l}\text { Thoughts that you would be } \\
\text { better off dead, or of hurting } \\
\text { yourself in some way? }\end{array}$ & $304(81.9)$ & $56(15.1)$ & $5(1.3)$ & $6(1.6)$ \\
\hline
\end{tabular}

Female students had substantially higher scores in social relationships compared to male, 10.50 vs 9.68 ( $p<0.05$ ). Students undergoing traditional mode of learning demonstrated significantly lower scores across all domains. Y4 students demonstrated the best total QoL score $(p=0.01)$ and highest scores across all domains except for the 'social relationships' domain. Different ethnicity, type of universities and accommodations did not show significant differences in the total QoL scores. On the other hand, significant associations were found between financial issues, weight changes, and physical activity state with total QoL scores.

Significant negative moderate correlation $(p=0.01)$ was found between stress vs quality of life ( $r s=-0.51$ ) and depression versus quality of life ( $r s=-0.59$ ), indicating lower stress and/or depression levels were associated with higher quality of life. Multivariate linear regression done to investigate the relationship between stress, depression and health-related quality of life was proved to be significant $(p<0.05)$, with $\mathrm{R}^{2}=0.46$, PSS-4 and PHQ-9 accounted for approximately $46 \%$ of the variance in QoL (Table V).

Table V: Assessment of Health-related Quality of Life using WHOQoL-BREF questionnaire $(n=371)$

\begin{tabular}{|c|c|c|c|c|c|}
\hline \multirow[t]{2}{*}{ Domain } & \multicolumn{3}{|c|}{ QoL level } & \multirow{2}{*}{$\begin{array}{l}\text { Mea n } \\
\text { score } \\
\left(\mathrm{SD}^{+}\right)\end{array}$} & \multirow{2}{*}{$\begin{array}{l}\text { Median } \\
\text { Score } \\
(\text { IQR++) }\end{array}$} \\
\hline & $\begin{array}{l}\text { Poor } \\
\text { N (\%) }\end{array}$ & $\begin{array}{l}\text { Moderate } \\
\text { N (\%) }\end{array}$ & $\begin{array}{l}\text { Good } \\
\text { N (\%) }\end{array}$ & & \\
\hline Physical health* & $95(25.6)$ & $193(52.0)$ & $83(22.4)$ & $\begin{array}{l}26.58 \\
(3.69)\end{array}$ & $\begin{array}{l}27.00 \\
(5.00)\end{array}$ \\
\hline $\begin{array}{l}\text { P s y c ho l o g ic a l } \\
\text { health** }\end{array}$ & $130(35.0)$ & $170(45.8)$ & 71(19.1) & $\begin{array}{l}20.53 \\
(3.44)\end{array}$ & $\begin{array}{l}21.00 \\
(4.00)\end{array}$ \\
\hline $\begin{array}{l}\text { Social relationships } \\
* * *\end{array}$ & $123(33.2)$ & 159(42.9) & $89(24.0)$ & $\begin{array}{l}10.32 \\
(1.81)\end{array}$ & $\begin{array}{l}11.00 \\
(2.00)\end{array}$ \\
\hline Environment $* * * *$ & $104(28.0)$ & $188(50.7)$ & $79(21.3)$ & $\begin{array}{l}20.97 \\
(4.36)\end{array}$ & $\begin{array}{l}30.00 \\
(6.00)\end{array}$ \\
\hline Total QoL score & $95(25.6)$ & $185(49.9)$ & $91(24.5)$ & $\begin{array}{l}94.76 \\
(12.08)\end{array}$ & $\begin{array}{l}96.00 \\
(15.00)\end{array}$ \\
\hline
\end{tabular}

Maximum possible scores: 35 points*, 30 points**, 15 points***, 40 points**** $\mathrm{SD}^{+}=$Standard Deviation

$\mathrm{IQR}^{++}=$Interquartile Range

\section{Discussion}

This study is considered the first of its kinds to evaluate the level of stress and depression and their impact on quality of life among Malaysian pharmacy students. It is essential to note that without considering the pandemic, university life is a phase which marks the onset of majority of mental disorders. These mental disorders are often indicated by predictors such as stress and depression which would lead to other severe mental illnesses when they are not addressed timely (McLafferty et al., 2017). The study initially investigated the demographic lifestyles of the pharmacy students during the period of the COVID-19 pandemic. While the global pandemic-imposed movement restrictions and lockdowns, it also brought about new responsibilities and activities for students to do which were non-academic related. These responsibilities include household chores, errands, and also assisting with ensuring that they are completing school work with the 
stringent conditions which the pandemic imposed on them (Lyons, Christopoulos, \& Brock, 2020). These findings demonstrate that some of Malaysian pharmacy students had other commitments besides study and spent more than six hours doing other tasks than studying and attending online classes. This indicates an additional layer of responsibilities which the students had other than their academic journey. These additional responsibilities are attributed to causing additional stress and depression among students, as it was a new phenomenon of keeping up with school work while taking extra care of the household, procuring personal protective equipment and doing grocery runs within the prescribed times of going outdoors before the curfew. Fischbein and Bonfine found that when there is an increase in the case of tasks given to an individual which seem impossible to perform for the students, it causes additional stress as there were financial loss and feelings of disappointment (Fischbein \& Bonfine, 2019). Therefore, given the additional responsibilities which students faced in the COVID-19 pandemic, there were high levels of stress and depression and a low in quality of life.

Students, which have significant external commitments outside of their studies, reported higher stress levels than those with fewer commitments. Some of the commitments which affected stress levels among students are family welfare, personal upkeep, and projected future prospects (Hirsch et al., 2020). In terms of family welfare, the global pandemic placed an increased necessity for students to be involved in their family welfare, especially those who have elderly family members and those with immunosuppressive conditions which meant a high risk outcome for contracting the virus. There was also the issue of family members who needed additional support in their living, and this coupled with the restrictive measure of the COVID-19 pandemic caused additional stress and depression which led to a lower quality of life (Goel et al., 2020). The personal welfare of students was also adversely affected by the COVID-19 pandemic as there were limited avenues which were previously available to manage stress and depression. In particular, the movement restrictions led to an increase in sedentary lifestyle among students even among those who were previously active. Exercise serves as a form of coping with stress in pharmacy students. The lack of essential activities triggered poor eating habits, poor food choices and a relapse into bad habits. The personal welfare of students was also affected by reduced income as some supporting family members lost their livelihoods due to the pandemic (Almaghaslah \& Alsayari, 2020; Hirsch et al., 2020). These factors increased the stress and depression in university students as evidenced by the poor QoL induced by the pandemic.

The perceived stress levels also indicate the impact of stress and depression on QoL in the era of the pandemic. This emergence situation impacted the academic calendar, as most of the academic terms were mid-way with impending examinations, assessments, and graduation. Schlesselman and colleagues (2020) demonstrated that these factors induced a feeling of helplessness in students, as indicated in this study's PSS-4 test that students felt they were unable to control the important things in their life. There was also the feeling of difficulties piling up for the students, which is explained by the inconvenience which the pandemic brought upon the students' welfare, heightening the extent of stress and depression (Schlesselman, Cain, \& DiVall, 2020). Despite the previous indicators of feeling additional pressure, however, the majority of students indicated a high level of confidence in resolving their personal problems. This finding counters the effect of stress and depression in the QoL of students during the pandemic. However, it is important to note that the pandemic has not yet been contained, and there is a potential wave which heightens the uncertainties of how life will be after the pandemic. Meanwhile, several plans of students continue to be postponed and delayed as the pandemic continues to claim lives and livelihoods across the globe. Malaysia, in January 2021 was facing the third wave with Conditional Movement Control Orders (CMCO) in progress as new cases had been recorded. Therefore, the optimism of students was rooted in the belief that the pandemic would be short-lived, but as it proves to be lasting longer, stress and depression indicators continue to rise (Almaghaslah \& Alsayari, 2020).

The findings showed increased levels of depression in the students. The majority of students had feelings of hopelessness and lack of interest in doing activities which they would previously do. The hopelessness in the pandemic was induced by the sudden news of the fatal virus, and the limited medical solutions to cure the virus. When one fails to find a possible solution to a problem which they or others are facing, it triggers hopelessness and feelings which lead to depression (Silva \& FigueiredoBraga, 2018). A lack of interest in doing things was influenced by the lockdown measures which restricted movement, and the sudden regulations of the virus which indicated the contagious nature of the virus. Therefore, this change in lifestyle, from regular activity and routines to extremely restricted movement conditions and the fear 
of contracting the COVID-19 virus, heightened depression levels in the students which would also lead to a poor QoL.

A particular finding on the investigation of depression in pharmacy students during the COVID-19 era is in the nature of symptoms which they had; Very few students felt as though they were better off dead or felt personal responsibility in having let their families or relatives down, which is a prevalent symptom in severe clinical depression. However, the noted symptoms were more inclined towards an interruption in regular lifestyle, the lack of access to the amenities which made life pleasurable and the interruption in the academic calendar and activities (Young \& Dietrich, 2015). This would, therefore, suggest that the COVID-19 pandemic was contributing to an increase in mild depression in the pharmacy students. Another perspective of the students' depression level is the presence of school counselling. Despite the majority of students being aware of the counselling services available at their institution, there have been very few students who utilised these services. This would suggest that very few students are interested in engaging in counselling services or acknowledging that they are having issues with their mental health. However, it is essential to acknowledge that cultural stigma which students might face in disclosing issues of stress and depression to the community might contribute not to use counselling services wisely. The students are in Malaysia, which is a multi-cultural society where issues of mental health are subjected to diverse perceptions which can deter disclosure of these struggles. Instead, it was noted that some of the students with stress and depression were also relying on poor lifestyle habits such as smoking, alcohol, drug abuse and binge eating to regulate their emotional wellbeing. Therefore, these habits, which used to curb stress and depression, can lead to a decline in the QoL of students, and within the context of the COVID-19 pandemic, these factors are highly amplified (Goel et al., 2020; Nahas et al., 2019).

Moreover, the current study also analysed QoL among pharmacy students, and only about a quarter of the students reported having a high quality of life during the COVID-19 pandemic. This suggests the comprehensive effects of the pandemic may affect the quality of life of the students, with the excess students indicating the declining quality of life as the pandemic progresses. A key observation was the relationship between healthy social relationships, lower stress levels and a higher quality of life. This would suggest that healthy social relationships among the students were helpful in reducing stress levels, as they provide comfort and assurance and thereby helping to improve the quality of life among students. This indicates that essential drivers of quality of life include the environment in which the students live (Lyons et al., 2020). It is recommended that students to regularly check their schedules and have time to spread their responsibilities to avoid becoming overwhelmed, which may trigger stress and depression. It is also essential to utilise the counselling services which are available at their institutions to get the available resources which can help them cope with university life, especially with the backdrop of COVID-19 pandemic. Additionally, both learners and teachers need to have progressive discussions on mental health issues in universities to reduce stigma and the use of unorthodox methods to cope with the transition from childhood to adulthood.

\section{Limitation}

There are several limitations which can be acknowledged in this study. As this a cross-sectional study, there is no baseline assessment for the quality of life for the students to compare to during the pandemic. This is because the study focused on an undergraduate project and there is a restricted time frame; further a longitudinal study design is required to explore these patterns further. The results of this study were collected while the pandemic is still in effect in Malaysia; thus it may not be the best to reflect the quality of life of the students under normal circumstances when there is no pandemic. In addition, the nature of the study design could not able to capture the real impact of the lockdown on the quality if life of the students. Therefore, further investigations need to be conducted after the pandemic to compare the findings with this study. Besides, some respondents provided incomplete results which could have provided further insights on their quality of life and how it has been impacted by the pandemic, which provides room for further studies to be conducted.

\section{Conclusion}

Stress and depression have a negative impact on QoL of pharmacy students in Malaysia, and this might be amplified by the lockdown and movement restrictions due to the COVID-19 pandemic. The pandemic has had not only effected the physical health of students, but it has carried with its significant psychological trauma which has led to a decline in quality of life. 


\section{Funding}

The authors declare that there was no funding for this work.

\section{Conflict of interest}

The authors declare that there is no conflict of interest regarding the publication of this paper.

\section{References}

AlAteeq, D.A., Aljhani, S., \& AlEesa, D. (2020). Perceived stress among students in virtual classrooms during the COVID-19 outbreak in KSA. Journal of Taibah University Medical Sciences, 15(5), 398-403. https://doi.org/10.1016/j.jtumed.2020.07.004

Alkatheri, A.M., Bustami, R.T., Albekairy, A.M., Alanizi, A.H., Alnafesah, R., Almodaimegh, H., Alzahem, A., Aljamaan, K., Zurnuq, S., \& Qandil, A.M. (2020). Quality of Life and Stress Level Among Health Professions Students. Health Professions Education, 6(2), 201-210. https://doi.org/10.1016/j.hpe.2019.11.004

Almaghaslah, D., \& Alsayari, A. (2020). The effects of the 2019 Novel Coronavirus Disease (COVID-19) outbreak on academic staff members: a case study of a pharmacy school in Saudi Arabia. Risk Management and Healthcare Policy, 13, 795

Aslan, I., Ochnik, D., \& Çınar, O. (2020). Exploring Perceived Stress among Students in Turkey during the COVID-19 Pandemic. International Journal of Environmental Research and Public Health, 17(23), 8961. https://doi.org/10.3390/ijerph17238961

Basudan, S., Binanzan, N., \& Alhassan, A. (2017). Depression, anxiety and stress in dental students. International journal of medical education, 8, 179

Bayram, N., \& Bilgel, N. (2008). The prevalence and sociodemographic correlations of depression, anxiety and stress among a group of university students. Social psychiatry and psychiatric epidemiology, 43(8), 667-672

Beiter, R., Nash, R., McCrady, M., Rhoades, D., Linscomb, M., Clarahan, M., \& Sammut, S. (2015). The prevalence and correlates of depression, anxiety, and stress in a sample of college students. Journal of affective disorders, 173, 90-96

Bidwal, M.K., Ip, E.J., Shah, B.M., \& Serino, M.J. (2015). Stress, drugs, and alcohol use among health care professional students: a focus on prescription stimulants. Journal of pharmacy practice, 28(6), 535-542

Brown, L.F., Kroenke, K., Theobald, D.E., Wu, J., \& Tu, W. (2010). The association of depression and anxiety with health-related quality of life in cancer patients with depression and/or pain. Psycho-Oncology, 19(7), 734-741

Cohen, S., Kamarck, T., \& Mermelstein, R. (1983). A global measure of perceived stress. Journal of health and social behavior, 385-396

Dyrbye, L.N., Thomas, M.R., Huschka, M.M., Lawson, K.L., Novotny, P.J., Sloan, J.A., \& Shanafelt, T.D. (2006). A multicenter study of burnout, depression, and quality of life in minority and nonminority US medical students. Mayo Clinic Proceedings, 81(11), https://doi.org/10.4065/81.11.1435

Fawzy, M., \& Hamed, S.A. (2017). Psychological stress among medical students in Assiut University in Egypt. Psychiatry Research, 255, 186-194. https://doi.org/10.1016/j.psychres.2017.05.027

Fischbein, R., \& Bonfine, N. (2019). Pharmacy and Medical Students' Mental Health Symptoms, Experiences, Attitudes and Help-Seeking Behaviors. American journal of pharmaceutical education, 83(10)

Goel, N., Haque, I., Bhyan, S. J., Jain, A., Kumari, A., Hamid, K., Sreelakshmi, M., Thomas, B., \& Chauhan, R. (2020). Impact of Covid-19 on Pharmacy Students in India. Preprints. https:// doi.org/10.20944/preprints202007.0702.v1

Gorczynski, P., Sims-Schouten, W., Hill, D., \& Wilson, J.C. (2017). Examining mental health literacy, help seeking behaviours, and mental health outcomes in UK university students. The Journal of Mental Health Training, Education and Practice

Gurková, E. (2011). Issues in the definitions of HRQoL. Journal of Nursing, Social Studies, Public Health and Rehabilitation, 3(4), 190

Hasanah, C.I., Naing, L., \& Rahman, A.R. (2003). World Health Organization Quality of Life Assessment: brief version in Bahasa Malaysia. The Medical Journal of Malaysia, 58(1), 79-88

Hennessy, C.H., Moriarty, D.G., Zack, M.M., Scherr, P.A., \& Brackbill, R. (1994). Measuring health-related quality of life for public health surveillance. Public health reports, 109(5), 665

Henning, K., Ey, S., \& Shaw, D. (1998). Perfectionism, the impostor phenomenon and psychological adjustment in medical, dental, nursing and pharmacy students. Medical education, 32(5), 456-464

Hirsch, J.D., Nemlekar, P., Phuong, P., Hollenbach, K.A., Lee, K.C., Adler, D.S., \& Morello, C.M. (2020). Patterns of Stress, Coping and Health-Related Quality of Life in Doctor of Pharmacy Students. American journal of pharmaceutical education, 84(3)

Hunt, K., \& Gable, K.N. (2013). Prevalence of depressive symptoms and obsessive-compulsive personality traits among pharmacy students. Currents in Pharmacy Teaching and Learning, 5(6), 541-545 
Ibrahim, M.B., \& Abdelreheem, M.H. (2015). Prevalence of anxiety and depression among medical and pharmaceutical students in Alexandria University. Alexandria Journal of Medicine, 51(2), 167-173

Keerthi, L. \& I. Madhuri. (2020). A Study on Impact of Stress on the Medical Students. IOSR Journal of Dental and Medical Sciences, 19(1), 1-3. https://doi.org/10.9790/0853-1901190103

Kroenke, L., Spitzer, R.L., \& Williams, J.B. (2001). The PHQ-9: validity of a brief depression severity measure. Journal of general internal medicine, 16(9), 606-613

Locke, D.E., Decker, P.A., Sloan, J.A., Brown, P.D., Malec, J.F., Clark, M.M., Rummans, T.A., Ballman, K.V., Schaefer, P.L., \& Buckner, J. C. (2007). Validation of single-item linear analog scale assessment of quality of life in neuro-oncology patients. Journal of pain and symptom management, 34(6), 628-638. https:// doi.org/10.1016/j.jpainsymman.2007.01.016

Lyons, K.M., Christopoulos, A., \& Brock, T.P. (2020). Sustainable pharmacy education in the time of COVID-19. American journal of pharmaceutical education, 84(6)

Marshall, L.L., Allison, A., Nykamp, D., \& Lanke, S. (2008). Perceived stress and quality of life among doctor of pharmacy students. American journal of pharmaceutical education, 72(6)

McCormack, Z., Gilbert, J.L., Ott, C., \& Plake, K.S. (2018). Mental health first aid training among pharmacy and other university students and its impact on stigma toward mental illness. Currents in Pharmacy Teaching and Learning, 10(10), 1342-1347

McLafferty, M., Lapsley, C.R., Ennis, E., Armour, C., Murphy, S., Bunting, B.P., Bjourson, A.J., Murray, E.K., \& O'Neill, S.M. (2017). Mental health, behavioural problems and treatment seeking among students commencing university in Northern Ireland. PLOS One, 12(12), https://doi.org/10.1371/journal.pone.0188785

Moutinho, I.L.D., Lucchetti, A.L.G., da Silva Ezequiel, O., \& Lucchetti, G. (2019). Mental health and quality of life of Brazilian medical students: Incidence, prevalence, and associated factors within two years of follow-up. Psychiatry Research, 274, 306-312

Nahar, V.K., Davis, R.E., Dunn, C., Layman, B., Johnson, E.C., Dascanio, J.J., Johnson, J.W., \& Sharma, M. (2019). The prevalence and demographic correlates of stress, anxiety, and depression among veterinary students in the Southeastern United States. Research in veterinary science, 125, 370-373. https://doi.org/10.1016/j.rvsc.2019.07.007

Nahas, A.R.M.F., Elkalmi, R.M., Al-Shami, A.M., \& Elsayed, T.M. (2019). Prevalence of depression among health sciences students: Findings from a public university in Malaysia. Journal of pharmacy \& bioallied sciences, 11(2), 170

Narakornwit, W., Pongmesa, T., Srisuwan, C., Srimai, N., Pinphet, P., \& Sakdikul, S. (2019). Quality of life and student life satisfaction among undergraduate pharmacy students at a public university in Central Thailand. Science, Engineering and Health
Studies (FORMER NAME 'SILPAKORN UNIVERSITY SCIENCE AND TECHNOLOGY JOURNAL'), 13(1), 8-19

Opoku-Acheampong, A., Kretchy, I. A., Acheampong, F., Afrane, B.A., Ashong, S., Tamakloe, B., \& Nyarko, A.K. (2017). Perceived stress and quality of life of pharmacy students in University of Ghana. BMC research notes, 10(1), 115

Paro, H.B., Morales, N.M., Silva, C.H., Rezende, C.H., Pinto, R.M., Morales, R.R., Mendonça, T.M., \& Prado, M.M. (2010). Healthrelated quality of life of medical students. Medical education, 44(3), 227-235. https://doi.org/10.1111/j. 1365-2923.2009.03587.x

Raosoft Inc. (2004). Sample size calculator (online). Available from: http://www.raosoft.com/samplesize.html

Ribeiro, I.J., Pereira, R., Freire, I.V., de Oliveira, B.G., Casotti, C.A., \& Boery, E.N. (2018). Stress and quality of life among university students: A systematic literature review. Health Professions Education, 4(2), 70-77

Sandhu, S.S., Ismail, N.H., \& Rampal, K.G. (2015). The Malay Version of the Perceived Stress Scale (PSS)-10 is a Reliable and Valid Measure for Stress among Nurses in Malaysia. The Malaysian journal of medical sciences : MJMS, 22(6), 26-31. Available from: https://pubmed.ncbi.nlm.nih.gov/28223882

Schlesselman, L.S., Cain, J., \& DiVall, M. (2020). Improving and Restoring the Well-being and Resilience of Pharmacy Students during a Pandemic. American journal of pharmaceutical education, 84(6)

Seo, E.J., Ahn, J.-A., Hayman, L.L., \& Kim, C.-J. (2018). The association between perceived stress and quality of life in university students: the parallel mediating role of depressive symptoms and health-promoting behaviors. Asian nursing research, 12(3), 190-196

Shamsuddin, K., Fadzil, F., Ismail, W.S., Shah, S.A., Omar, K., Muhammad, N.A., Jaffar, A., Ismail, A., \& Mahadevan, R. (2013). Correlates of depression, anxiety and stress among Malaysian university students. Asian journal of psychiatry, 6(4), 318-323. https://doi.org/10.1016/j.ajp.2013.01.014

Sherina, M.S., Arroll, B., \& Goodyear-Smith, F. (2012). Criterion validity of the PHQ-9 (Malay version) in a primary care clinic in Malaysia. The Medical Journal of Malaysia, 67(3), 309-315

Silva, R.G., \& Figueiredo-Braga, M. (2018). Evaluation of the relationships among happiness, stress, anxiety, and depression in pharmacy students. Currents in Pharmacy Teaching and Learning, 10(7), 903-910

Unni, E.J., Madrid, L., Oderda, G., \& Saokaew, S. (2015). Quality of life of pharmacy students in the United States. Currents in Pharmacy Teaching and Learning, 7(6), 753-763

Vallejo, M.A., Vallejo-Slocker, L., Fernández-Abascal, E.G., \& Mañanes, G. (2018). Determining factors for stress perception 
assessed with the Perceived Stress Scale (PSS-4) in Spanish and other European samples. Frontiers in psychology, 9, 37

WHOQOL Group. (1998). Development of the World Health Organization WHOQOL-BREF quality of life assessment. Psychological medicine, 28(3), 551-558

Xu, Y., Chi, X., Chen, S., Qi, J., Zhang, P., \& Yang, Y. (2014). Prevalence and correlates of depression among college nursing students in China. Nurse education today, 34(6)

Yang, C., Chen, A., \& Chen, Y. (2021). College students' stress and health in the COVID-19 pandemic: The role of academic workload, separation from school, and fears of contagion. PLoS One, 16(2), https://doi.org/10.1371/journal.pone.0246676

Young, C.C., \& Dietrich, M.S. (2015). Stressful life events, worry, and rumination predict depressive and anxiety symptoms in young adolescents. Journal of Child and Adolescent Psychiatric Nursing, 28(1), 35-42 